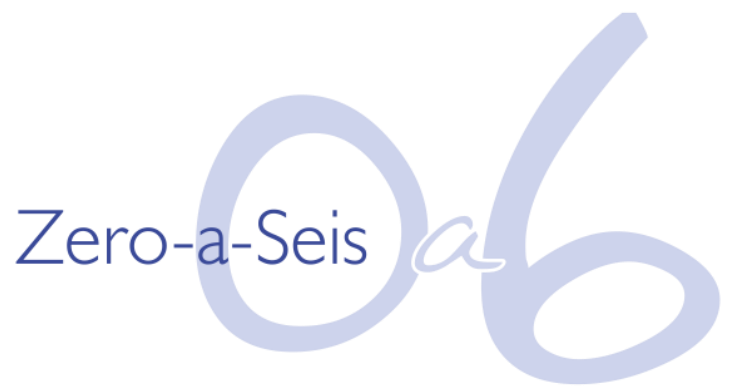

\title{
CRIANÇAS EM BUSCA DE REFÚGIO: REFLEXÕES SOBRE AS SOLICITAÇÕES INFANTIS DE REFÚGIO AO BRASIL ATÉ 2016
}

\author{
Children looking for refuge: reflections on child refugee requests to Brazil until \\ 2016
}

\author{
Monique Roecker LAZARIN \\ Universidade Federal de São Carlos \\ São Paulo, Brasil \\ moniquelazarin@gmail.com \\ https://orcid.org/0000-0001-7414-9738
}

\author{
Anete ABRAMOWICZ \\ Faculdade de Educação \\ Universidade de São Paulo \\ São Paulo, Brasil \\ aneteabramo@gmail.com \\ https://orcid.org/0000-0002-4714-3602 (i)
}

A lista completa com informações dos autores está no final do artigo

\begin{abstract}
RESUMO
O presente estudo faz parte de um campo teórico de debate sobre a confluência entre as temáticas da infância e da migração forçada. Mais especificamente, faz uma análise da formação da infância refugiada no Brasil, a partir de uma de suas facetas: as solicitações de crianças registradas no Comitê Nacional para Refugiados. Essa análise está centrada na estatística descritiva do perfil de tais crianças, com base em dados disponibilizados pelo CONARE em 2017, constando os casos registrados até abril de 2016. Para esse intuito, o artigo parte de um tópico reflexivo sobre significados sociais da demanda por refúgio, para então passar à descrição quantitativa das solicitações infantis. Com base nesses dois tópicos, o artigo traz reflexões sobre a configuração da busca de crianças por refúgio nacionalmente e sobre a conexão dos movimentos migratórios refugiados com as distintas categorias geracionais. Em síntese, debate sobre a reverberação no Brasil dos fluxos derivantes da não garantia da proteção da vida de crianças em seu país de origem.
\end{abstract}

PALAVRAS-CHAVE: Crianças refugiadas. Migrações internacionais. CONARE.

\section{ABSTRACT}

The present study is part of a theoretical field that debates about the confluence between the themes of childhood and forced migration. More specifically, it analyzes the formation of refugee children in Brazil, based on one of its facets: requests from children registered with the National Committee for Refugees. This analysis is centered on the descriptive statistics of the profile of such children, based on data made available by CONARE in 2017, listing the cases registered until April 2016. For this purpose, the article starts from a reflective topic on social meanings of the demand for refuge, and then it presents the quantitative description of children's requests. Based on these two topics, the article brings reflections on the configuration of the search for children for refuge nationally and on the connection of migrant refugee movements with the different generational categories. In summary, debate on the reverberation in Brazil of the flows derived from the non-guarantee of protecting the lives of children in their country of origin. KEYWORDS: Refugee children. International migrations. CONARE. 


\section{INTRODUÇÃO}

Este artigo pretende debater a migração refugiada que se configura como uma das grandes questões sociais da contemporaneidade. Os números alertam isso: segundo dados do Alto Comissariado das Nações Unidas para os Refugiados (ACNUR), lançado em 2019, o número de pessoas em deslocamento forçado, em 2018, atingiu o patamar mais alto já registrado pela instituição, compondo um total de 70,8 milhões de indivíduos (25,9 milhões de refugiados, 41,3 milhões de deslocados internos e 3,5 milhões de solicitantes de asilo). Esse tipo de deslocamento tem contado com uma participação massiva de crianças e adolescente, sendo que estes chegam a compor mais da metade dos refugiados a nível global (ACNUR, 2019). No Brasil poucos são os dados que traduzem o perfil da população refugiada considerando esse detalhamento geracional. Tomando em consideração a importância da força e intensidade que os fenômenos migratórios possuem com a infância, enquanto categoria social geracional (QVORTRUP, 2011), esse estudo tem por objetivo apresentar alguns pontos relativos a temática das crianças refugiadas. Mais especificamente, o objetivo é compreender que infância refugiada está sendo formada no Brasil a partir do entendimento do perfil quantitativo das crianças que tem solicitado este abrigo no Brasil.

Contudo, antes de buscar traçar o perfil dessa faceta da infância refugiada, se faz necessário compreender o que significa, sob o ponto de vista sociológico, essa busca por refúgio a qual as crianças estão fazendo. Essa busca é aqui analisada como um conflito no bojo do ideal do Estado-Nação, conflito esse que se complexifica com as dinâmicas atuais da globalização capitalista. Sob essa ótica, os refugiados são aqueles sob a qual a governamentalidade ${ }^{1}$ atua pela expulsão.

Esse artigo, portanto, está estruturado em dois tópicos. O primeiro, aborda visões sociológicas sobre o fenômeno do refúgio. Por se tratar de uma questão complexa, esse artigo resume algumas das principais argumentações sobre assunto, passiveis de contestações. O segundo tópico, detalha quantitativamente os dados sobre crianças que solicitaram refúgio no Brasil. Este detalhamento foi feito a partir da análise de dados disponibilizados pelo Comitê Nacional para os Refugiados (CONARE) constando as solicitações de refúgio até Abril de $2016^{2}$.

\footnotetext{
${ }^{1}$ Michel Foucault define este conceito em sua obra "Segurança, Território e População", se caracteriza como o governo da população, biopolítica.

2 Disponiblizada em 2017 no site do então Ministério da Justiça. A data de início dos processos equivale a data de criação do CONARE, o ano de 1998.
} 


\section{SIGNIFICADOS DA BUSCA POR REFÚGIO}

Para entender sobre a temática das crianças refugiadas é importante analisar o que essa busca reflete, ou quais raízes sociais estão por trás da tentativa de obter tal status. Obviamente existem estratégias individuais e familiares nas trajetórias migratórias, fazendo com que o refúgio seja fortemente visado como forma de adentrar em um país (ZANFORLIN, 2013) ${ }^{3}$. Não se ignora que nem todo solicitante está em condições que caracterizam o refúgio, tal como é definido nas legislações internacionais; mas, de qualquer forma, há que se considerar que pleitear esse status é uma maneira encontrada para adquirir proteção e abrigo em um outro Estado. Afinal, as lógicas individuais de mobilidade estão vinculadas às gestões estatais dos fluxos migratórios (PERALVA; TELLES, 2015).

Posta tal ressalva, a definição de refugiado que fundamenta esse estudo é aquela estabelecida por Agamben (2007, p. 141), quando afirma que: "O refugiado deve ser considerado por aquilo que ele é, ou seja, nada menos que um conceito-limite que põe em crise radical as categorias fundamentais do Estado-Nação, do nexo nascimentonação àquele homem-cidadão". Tal definição põe em tensão alguns dos conceitos mais imprescindíveis à existência do refúgio, a saber: Estado, Nação, Cidadão. Intenta-se demonstrar que, apesar de historicamente os direitos das pessoas estarem estabelecidos, sobretudo pela sua nacionalidade, e, portanto, sendo de responsabilidade dos Estados, a nascença cada vez menos traz a garantia da cidadania. Isso devido a governamentalidade de uma população, com base em um ideal de Nação, que implica a expulsão de determinados corpos. Contemporaneamente, esses conflitos no bojo do Estado-nação são ainda acirrados com as dinâmicas da globalização capitalista. Tal argumentação é importante contraponto à iconografia da imprensa internacional sobre o refúgio, que por vezes cria imaginários do deslocamento como movimento pautado no abandono, dando a sensação de que o refugiado é, então, fruto de uma não governança, por ser aquele sem um governo para protegê-lo. De certa forma, o refúgio está sim erigido nesse limbo jurídico em que fica a pessoa em deslocamento forçado.

\footnotetext{
${ }^{3}$ Zanforlin (2013, p. 136) debate a imagem do refugiado e do migrante, abordando as estratégias a partir da seguinte proposição: "[...] o status de refugiado pode ser buscado pelo migrante como estratégia facilitadora de pertencimento na tentativa de rápida regularização da sua situação burocrática. Como parte dessa estratégia, o migrante, a partir da troca de informações com sua rede de contatos, esta troca inclui o uso de e-mail e redes sociais, constrói um discurso focado nas possibilidades de obter o refúgio, pela alegação de violência generalizada, medo da morte, ou pelo cerceamento da liberdade de expressão, por exemplo".
} 
Contudo, essa condição jurídica é antes social e pautada na história da governamentalidade global de pessoas com base na divisão dos Estados-Nação. Assim, para que exista alguém em situação de refúgio é preciso compreender essa existência alicerçada em formas específicas de gestão da vida.

A questão da governamentalidade foi base fundamental dos estudos de Foucault, entre 1975-1976 em "Em Defesa da Sociedade" e 1978-1979 em "Nascimento da Biopolítica" (em texto de 2008). Quando o filósofo expõe sobre o porquê de refletir sobre isso, afirma que a resposta imediata para tal pergunta é a de abordar o problema do Estado e da população. Para Foucault (2008), a base originária do Estado é a razão governamental, isto é, o aparato estatal emerge a partir da necessidade de racionalizar a arte de governar. É a necessidade de instrumentalização, de otimização, de organização da governamentalidade a razão de ser do Estado. Uma vez sendo o coordenador dessa razão política, o Estado acaba também se transformando no determinante do estado ideal das coisas. Em outras palavras, o Estado surge em função da racionalidade política, mas, nesse percurso, acaba se transformando em seu próprio objetivo: "O Estado é, portanto, o princípio de inteligibilidade do que é, mas também é o que deve ser" (FOUCAULT, 2008, p. 385). Acontece que, por mais que o Estado tenha essa pretensão de garantir e ao mesmo tempo ser a própria manutenção da ordem, a governamentalidade é do campo da gestão das pessoas, da população, pois, segundo o filósofo (2008), nunca se governa um Estado, um território ou uma estrutura política: quem é governado são pessoas - individual ou coletivamente. O poder, como operação da governamentalidade, é que se utiliza dessa organização da soberania estatal. As tecnologias de poder e formas de governamentalidade são alteradas ao longo dos processos históricos e a forma do Estado-Nação implica, justamente, em um governar específico de pessoas.

Retornando a questão específica do refúgio, tem-se que sendo este um processo migratório, uma das principais distinções das demais modalidades de deslocamento está nas "razões de partir" (TRINDADE, 1995, p. 42): "aplica-se a populações que se encontram inopinadamente em situação de total privação de recursos que assegurem, sequer, a sua sobrevivência". Nesse sentido, o refúgio está circunscrito dentro do conjunto de migrações forçadas, originada em motivações emergenciais. Ou seja, um fluxo compulsório enraizado nas condições sociais de precariedade. Esse deslocamento emergencial pode se dar pelo atravessar das fronteiras internacionais ou pelo 
deslocamento dentro do seu próprio país; neste caso, são considerados deslocados internos ${ }^{4}$.

Tais definições revelam que a emergência do refugiado só existe em um mundo de fronteiras: fronteiras, nesse caso, estatais. Assim, a própria definição de refúgio está em concordância com a definição de governamentalidade da população baseada no aparato estatal: o refugiado é aquele que tem que sair de um Estado específico, aquele que tem que atravessar a fronteira que delimita o território onde é válido internacionalmente a soberania de um Estado. Essa governamentalidade por apagamento da existência em um território soberano só se faz possível porque historicamente foi sendo construída a ideia - bem como as tecnologias para instrumentalizar na prática tal ideia - de que um Estado é o agrupamento básico/elementar/fundamental de pessoas (ELIAS, 1994), sendo que a definição de quem são essas pessoas que formam um grupo nacional se dá, sobretudo, pelo lugar de nascimento. Ou seja, passam a pertencer a um referido agrupamento, centralizado sobre a ordenação de um Estado específico, aqueles indivíduos que nasceram no território delimitado como pertencente a tal país. Essa organização, que orienta uma das principais formas de governamentalidade de pessoas na modernidade, tem como marcação histórica o evento acontecido em 1648: o Tratado de Vestfália. Desde Vestfália, a soberania territorial passa a ser um dos pilares da construção política e definição jurídica de um Estado (APPADURAI, 1997), logo, as fronteiras geográficas passam a delimitar os limites da soberania estatal.

A formação do Estado moderno no Ocidente começa com a 'territorialização' do espaço. [...] Neste modelo 'westfaliano', a integridade territorial e uma autoridade jurisdicional unificada são dois lados da mesma moeda; proteger a integridade territorial é a outra face do poder do estado para reivindicar sua autoridade jurisdicional (dominium). (BENHABIB, 2012, p. 26)

O Tratado de Vestfália foi significativo porque, após a Guerra dos Trinta Anos, traçou a base do que seria o sistema de política internacional a partir de então, pautando a diplomacia (como alternativa à guerra), a soberania territorial dos Estados e a igualdade dos Estados Soberanos. É neste momento histórico, afirma Foucault (2008), que se criam bases para sair de um universalismo de gestão, tal qual pretendido pelo cristianismo, e passa-se a conceber como elemento central a pluralidade de Estados.

\footnotetext{
4 Agência da ONU para refugiados define deslocados internos: "São pessoas deslocadas dentro de seu próprio país, pelos mesmos motivos de um refugiado, mas que não atravessaram uma fronteira internacional para buscar proteção. Mesmo tendo sido forçadas a deixar seus lares por razões similares às dos refugiados (perseguições, conflito armado, violência generalizada, grave e generalizada violação dos direitos humanos), os deslocados internos permanecem legalmente sob proteção de seu próprio Estado mesmo que esse Estado seja a causa de sua fuga" (ACNUR-Brasil, s/d, texto eletrônico).
} 
Ou seja, emerge a concepção de que a paz não viria da unidade, mas da pluralidade mantida enquanto tal.

A população mundial é, então, separada por limitações estatais. Cada uma destas unidades aparece como uma nação, sendo a nação esse vínculo forjado entre aqueles que existem em um território comum e, por conseguinte, que estão perante a mesma soberania. Segundo Agamben (2002), é a falência do antigo regime, do reinado monárquico, que marca o nascimento do Estado-Nação, quando se une o princípio da natividade ao princípio da soberania: antes o nascimento dava origem ao súdito, agora origina um sujeito, que será interligado ao corpo soberano. Ou seja, as fronteiras do Estado-Nação passam também a delimitar os corpos dos que ali nascem sob a inscrição da nacionalidade. Para a questão dos direitos essa relação é importante, pois estabelece a ordem mundial de proteção dos indivíduos: é a passagem do súdito ao cidadão. É a partir dessa unidade política, definida nas fronteiras territoriais de poder do Estado soberano, que se garantem os direitos sociais. Ser nacional significaria, idealmente, ter vínculo com um Estado e estar inscrito em uma vinculação jurídica de deveres e direitos civis e político; em outras palavras, é ter direito a cidadania.

Nacionalidade e cidadania, contudo, nunca significaram vínculo imediato e direto. Ao longo da história dos Estados percebemos vários casos disso; injustiças que inclusive geraram movimentos sociais em busca por reconhecimento de cidadania ${ }^{5}$. Estes conflitos em torno da cidadania, segundo Carvalho (1996), não podem ser desvinculados da ideia de nação da qual o Estado pretende ser o regente - quando à cidadania esbarra na formação pretendida de identidade nacional. Apesar de existirem critérios jurídicos determinados para concessão de nacionalidade (o jus soli e o jus sanguinis), na prática, encontram-se ao redor do mundo diversos exemplos de disputas em torno do reconhecimento de grupos sociais enquanto parte da unidade social pretendida enquanto nação.

Nação pode ser entendida enquanto uma comunidade política imaginada, com limitações de fronteiras e soberania (ANDERSON, 2008). Isso implica que, tanto a condição nacional quanto o nacionalismo (ou o sentimento de nacionalidade), são produções culturais ${ }^{6}$, não sendo da dimensão da falsidade/autenticidade, mas sim da

\footnotetext{
5 José Murilo de Carvalho (1996) recorda que no Brasil, por exemplo, três questões sociais estiveram ligadas a seletividade da cidadania: a escravidão, o patriarcalismo e o latifúndio. Para os impactados negativamente por tais estruturas, a busca pela cidadania se deu a partir de uma luta ativa.

${ }^{6}$ Como historiador, Anderson (2008) não deixa de descrever a conjuntura histórica que possibilitou a efervescência do sentimento nacional. Para ele, três foram as grandes raízes históricas que possibilitaram tal transição na Europa Ocidental no século XVIII: o declínio do pensamento religioso; do reino dinástico;
} 
ordem do estilo em que são imaginadas. Contudo, para Anderson (2008), a nação implica em um sentimento de horizontalidade e confiança entre os seus. Aqui, o que está focalizado não é essa relação de um certo sentimento de homogeneidade; ao contrário, evidencia-se que a construção dessa comunidade imaginada enquanto unidade se dá a partir do apagamento de certas existências tidas como não condizentes à proposta de nação.

Para entender a forma como se criam tais separações e fragmentações dentro da população de uma Nação, voltamos a recorrer a Foucault (1999) com os conceitos de biopolítica e racismo de Estado. A biopolítica, segundo o autor, é o poder que trouxe a governamentalidade para chave da população. A partir da conexão entre o poder disciplinar, que já lidava com indivíduo-corpo, com essa nova tecnologia de poder, os corpos são alocados no conjunto. Para Foucault (1999), diferentemente do Estado baseado na soberania real, que tinha seu poder no "fazer morrer" e "deixar viver" seus súditos, a passagem do Estado Moderno está fortemente pautada no processo de poder "fazer viver" e "deixar morrer". Mas, não todas as vidas pretende-se "fazer viver", são vidas que interessam à governamentalidade; nesse caso, vidas que se conformam ao projeto de nação articulado pelo Estado. Para tal separação das vidas, segundo Foucault (1999), a biopolítica inseriu o racismo nos mecanismos de operação estatal. Logo, há a emergência, juntamente com gestão das populações, do Racismo de Estado - se transformando este numa técnica de poder: "Essa é a primeira função do racismo: fragmentar, fazer cesuras no interior desse contínuo biológico a que se dirige o biopoder" (FOUCAULT, 1999, p.305). Com o racismo, a guerra dentro do próprio corpo social deixa de ser vista como somente eliminação e destruição, para também ser vista como regeneração. Elimina-se determinadas vidas do conjunto como forma de construção e manutenção da nação7. O refugiado surge, nesse contexto, como corpo que foi retirado dessa comunidade imaginada como nação, que não cabe dentro da homogeneidade pretendida. Sobre ele, o poder biopolítico opera pela faceta do racismo, expulsando-o do território em que vivia: dentro desse contínuo e homogêneo para o qual se dirige a biopolítica - a população - , a tecnologia do racismo atua identificando essas células não condizentes ao projeto de organização do conjunto expulsando-as.

É importante sublinhar que todo esse processo pautado na ideia de unidade entre Estado-Nação-Território não significa que os governos estatais tenham agido de forma

e a mudança na percepção temporal. Com tais mudanças, o capitalismo editorial foi essencial na união e criação de uma fraternidade que desse origem a uma consciência nacional.

7 O caso mais evidente disso, segundo Foucault (1999), é o nazismo. 
a se tornarem unidades isoladas e deixado de operar sobre populações de outros territórios, pois o intercâmbio entre pontos globais continuou a existir mesmo depois da formação dos Estados-Nação. As exemplificações máximas disso são: 1) no passado, os empreendimentos imperialistas e 2) contemporaneamente, a globalização capitalista, sendo este ponto fundamental na configuração dos conflitos atuais.

Quanto ao primeiro, a que se considerar que o Tratado de Vestfália tratou das soberanias estatais considerando a formação de um continente específico, a Europa. 0 tratado foi uma tentativa de manter o equilíbrio dos países de tal continente e, assim, evitar a guerra entre eles. Obviamente, aí se tem uma questão não limitada a Europa: buscava-se apaziguar os conflitos e estabelecer a paz entre os Estados dessa comunidade; mas, ao mesmo tempo, tratava sobre a relação com o mundo inteiro, a partir da dominação econômica e colonizadora. A relação entre fronteiras e soberania não é fixa, e em diversos momentos da história viu-se a expansão do poder do Estado para além do território do país, como é o caso dos empreendimentos imperialistas. Mbembe (2018) recorda que os dois princípios da Ordem Jurídica Europeia (igualdade jurídica de todos os Estados e territorialização do Estado soberano) não valeram para as colônias, não sendo, portanto, a colonização vista como guerra. O autor ainda argumenta que essa não validação jurídica está pautada na negação racial entre colonizador e colônia: utilizando a ideia de alienígena, afirma que na colônia não se via nas pessoas um caráter humano, mas sim selvagem ${ }^{8}$. Não concebendo aquelas mortes como massacre de vida humana, a ocupação colonial buscou, a todo custo, a territorialização da soberania dos Estados colonizadores.

Para Benhabib (2012), as próprias migrações atuais são legado de tal imperialismo. São movimentos decorrentes da ação histórica das migrações de colonização e exploração, com uma divergência central de forma: o imperialismo buscava impor aos novos territórios a jurisdição e controle pretendido pela colônia; já os fluxos de hoje não estão pautados na busca por tal imposição dos deslocados. Pelo contrário, os imigrantes ficam inseridos em uma multiplicidade de jurisdições ao atravessar as fronteiras.

\footnotetext{
${ }^{8}$ Nessa diferenciação está atrelada a dualidade entre natureza e cultura na justificação da colonização. Ou seja, os colonizadores viam os moradores da colônia como parte da natureza; e os massacres, por isso, não tinham o peso de crime: "Por todas essas razões, o direito soberano de matar não está sujeito a qualquer regra nas colônias. [...] A guerra colonial não está sujeita a normas legais e institucionais. [...] A paz não constitui necessariamente a consequência natural de uma guerra colonial. De fato, a distinção entre guerra e paz não é pertinente. As guerras coloniais são concebidas como a expressão de uma hostilidade absoluta que coloca o conquistador face a um inimigo absoluto" (MBEMBE, 2018, p. 36-37).
} 
Este legado do império voltou hoje a assombrar os países ricos em recursos do Hemisfério Norte pelo aumento das migrações transnacionais. Migrações transnacionais também produzem um desacoplamento entre territorialidade, soberania e cidadania, mas de uma forma bem diferente do que o colonialismo. Ao passo que nos séculos dezenove e vinte, o imperialismo europeu disseminou formas de jurisdição em territórios coloniais que eram protegidas do consentimento e do controle democráticos, movimentos migratórios contemporâneos dão origem a jurisdições sobrepostas que são frequentemente protegidas por normas internacionais. (BENHABIB, 2012, p. 28, grifos do autor).

Isto posto, aponta-se para o outro ponto 'a globalização capitalista', para discorrer como, contemporaneamente, as disputas no seio do território nacional, que levam pessoas a se refugiar, não pode ser desvinculada do capitalismo global. Segundo Appadurai (1997), os conflitos estão centrados no que até então se retratou aqui como o ideal de isomorfismo do Estado-Nação, na pretensa conexão una entre povo, território e soberania. Na conjuntura contemporânea deve-se levar em consideração a intensificação dos fluxos de pessoas, mercadorias e comunicação, que faz surgir formas distintas do como o Estado e a população se relacionam com a ideia de território e nação:

\begin{abstract}
Estas disjunções nos vínculos entre espaço, lugar, cidadania e nacionalidade levam a várias implicações de longo alcance. Uma delas é que o território e a territorialidade são crescentemente a base lógica crítica da legitimação e do poder do Estado, enquanto as concepções de nação são cada vez mais atraídas por outros discursos de lealdade e afiliação - às vezes linguístico, às vezes racial, às vezes religioso, mas muito raramente territorial. (APPADURAI, 1997, p.39)
\end{abstract}

Essa crescente distinção está inserida em um mercado global de lealdades (PRICE, 1994 apud APPADURAI, 1997), no qual o Estado e sua ideia de nação está em competição direta com os outros centros aos quais a população tem fidelidade. Isso significa uma acentuação da disputa entre a Soberania Estatal e a Soberania Popular (BENHABIB, 2012), fazendo com que o Estado tenha que lidar diretamente com esse mercado global de lealdades para conseguir manter sua legitimidade. Quando conexões com interesse do capitalismo internacional entram em conflito com as propostas de Estado, interesses globais dominantes podem agir de forma a incentivar crises nacionais, tais como visto recentemente em países da América Latina e do Oriente Médio. A colonização, nesse sentido, não se dá somente de um Estado por outro: a formação da identidade nacional está diretamente dependente à abertura ao capital internacional. Obviamente, países de relação de dominação e que são beneficiados com o que se pode explorar internamente e compartilhar de forma desigual externamente também possuem influência nos conflitos.

Sassen (2016), ao refletir sobre isso, discorre sobre o que chamou de tendências subterrâneas: para ela, por trás das diversas crises globais existem dinâmicas operando 
em uma nova lógica sistêmica emergente; são materializações de tendências globais de livre busca de lucro dentro das fronteiras nacionais. A autora utiliza, então, o termo "expulsões" para discorrer sobre o crescente número de refugiados. O termo tem proposição causal, ressaltando que existe princípio originador. Para a autora, uma desigualdade crescente - patologia do capitalismo global - faz surgir o que nomeou de "novas lógicas de expulsão". Os meios para tal expulsão podem variar muito9 , mas em comum possuem o fator extremo, violento, do processo. Sassen (2016, p.262) diferencia o capitalismo hoje de suas formas iniciais a partir, justamente, da brutalidade que tem gerado, não atuando mais no limite da incorporação: "O limite sistêmico hoje é um espaço de expulsões, em comparação com a época keynesiana, em que o limite do sistema era um espaço de incorporação, não porque fosse um período ideal, mas porque as sistematicidades constitutivas incluíam a produção e o consumo em massa. Hoje não é mais assim."

Nesse sentido, compara a expulsão a um "processo de seleção selvagem", argumentando que as capacidades das finanças gerarem capital e deste ser materializado em bem-estar social não obstrui um caminho oposto, da desigualdade, onde qualquer pessoa que se mostre como empecilho ao capital pode ser rejeitada. Logo, a denúncia que a autora faz - e que interessa ao presente escrito - é que não se trata de movimento neutro de emigração, mas sim de uma expulsão ${ }^{10}$. Tais expulsões se dão por forças destrutivas que dificilmente são mapeáveis. "Aqui, a complexidade é parte da condição. Quanto mais complexo um sistema é, mais difícil é de entender, mais difícil é de assinalar com precisão as responsabilidades, e mais difícil é que qualquer pessoa dentro dele se sinta responsável" (SASSEN, 2016, p.256).

Estas forças destrutivas ocultas que levam aos conflitos contemporâneos, nos termos de Sassen (2016), são também operacionalizadas por Mbembe (2018), mas com a ideia de máquinas de guerra, a partir da qual pondera sobre as guerras travadas

\footnotetext{
${ }^{9}$ Além dos refugiados, a autora cita, por exemplo, as expulsões provenientes das mudanças climáticas e aquelas decorrentes da especulação imobiliária.

${ }^{10} \mathrm{~A}$ autora fala especificamente sobre o caso dos refugiados sírios, em uma entrevista dada para a revista Ponto e Vírgula, em 2015: "Nós, no Ocidente, mais uma vez, geramos um fluxo maciço de refugiados. E é realmente difícil entender por que fizemos isso seja qual for a análise. Mas nós fizemos, nós bombardeamos, nós matamos, criamos uma divisão enorme entre xiitas e sunitas. Sim, uma grande desconfiança uns dos outros. A invasão do Iraque e o manuseio do pós invasão só trouxe essa divisão a um ponto mais acentuado. Assim, a Síria acabou de receber mais de 2 milhões de sunitas depois da guerra 'sucesso' dos Estados Unidos e seus aliados e a implementação de um regime que perseguiu sunitas transformando-os em um inimigo que agora é parcialmente cristalizado no Estado Islâmico, com Falluja, uma de suas principais bases até recentemente. Muitos desses refugiados chegando à Europa são produtos dessas guerras lançadas pelos Estados Unidos e alguns de seus aliados" (SASSEN apud FELIX, 2015, p.172).
} 
em territórios nacionais em época de globalização. Para Mbembe (2018), estamos frente a uma era de mobilidade global em que o exercício do direito de matar não está sob monopólio exclusivo dos Estados. Nesse movimento, também se tornam mais borradas as fronteiras entre o interno e o externo, implicando no que nomeia de "organização heteronômica de direitos territoriais". Ou seja, existe uma complexificação das guerras com atuação de diversos atores internacionais nos conflitos nacionais, fortalecendo uma economia que traz uma distinção abismal entre os detentores ou não de armas. O Estado tem sua atuação imbricada também nesse jogo, buscando o fortalecimento da militarização, sobretudo de controle de fronteiras, na tentativa de reafirmar sua soberania (Benhabib, 2012), ou se alinhando com alguns grupos armados a agir no território.

Cada vez mais, a guerra não ocorre entre exércitos de dois Estados soberanos. Ela é travada por grupos armados que agem por trás da máscara do Estado contra os grupos armados que não têm Estado, mas que controlam territórios bastante distintos; ambos os lados têm como seus principais alvos as populações civis desarmadas ou organizadas como milícias. (MBEMBE, 2018, p. 60).

Ou seja, toda aquela organização global baseada no ideal da soberania dos Estados é posta em questão dentro dos movimentos do capitalismo e da globalização. É por isso que, voltando à definição de Agamben (2007), existe uma crise radical em torno da configuração do Estado-Nação, pois o Estado já não tem a autonomia e poder necessário para ser o grande gestor das vidas. Dentro desse panorama de complexificação e brutalidade dos conflitos internos atuais, emergem essas corporeidades matáveis, pessoas que vão buscar asilo em outros espaços como forma de preservação da vida.

Com esse panorama evidencia-se que o refugiado deve ser considerado não como caso individual, mas como um fenômeno de massa crescente, acirrado com o crescimento da crise das categorias fundamentais do Estado-Nação moderno, frente aos contextos que desafiam a ficção da soberania estatal. Uma ruptura entre nascimento, nacionalidade e cidadania, que marca a governamentalidade da população via expulsão. O deslocamento surge, então, como busca de territórios em que a gestão predominante reconheça a validade da vida e a precariedade social de quem teve que emigrar. A existência resiste em espaços de exceção ${ }^{11}$, tais como sítios humanitários

\footnotetext{
11 Para Agamben (2004), Estado de Exceção é aquele que toma a legalidade, sob suspensão da ordem jurídica e da normalidade, daquilo que não poderia ter forma legal: a normalidade da exceção.
} 
$\left(\right.$ AGIER, 2006) ${ }^{12}$, ou a partir do pleiteio por acolhimento e reconhecimento, enquanto refugiado, a um outro Estado nacional. Esta forma de resistência reflete-se nos dados analisados a seguir: processos de pessoas que solicitaram ao Brasil o status de refugiadas - entre elas pelo menos 1.910 eram crianças.

\section{AS SOLICITAÇÕES DE CRIANÇAS POR REFÚGIO AO BRASIL}

A tabela divulgada pelo Comitê Nacional para os Refugiados indica que - até 29 de abril de 2016 - foram recebidas 38.782 solicitações de refúgio. Desses $1.910^{13}$ são processos referentes a indivíduos registrados na tabela como tendo 12 anos incompletos no momento da solicitação, além de 893 adolescentes e 33.678 adultos $^{14}$ (em 2.301 casos a idade na solicitação era desconhecida), conforme compilado no gráfico abaixo (Figura 1).

Figura 1: Solicitantes por grupo etário

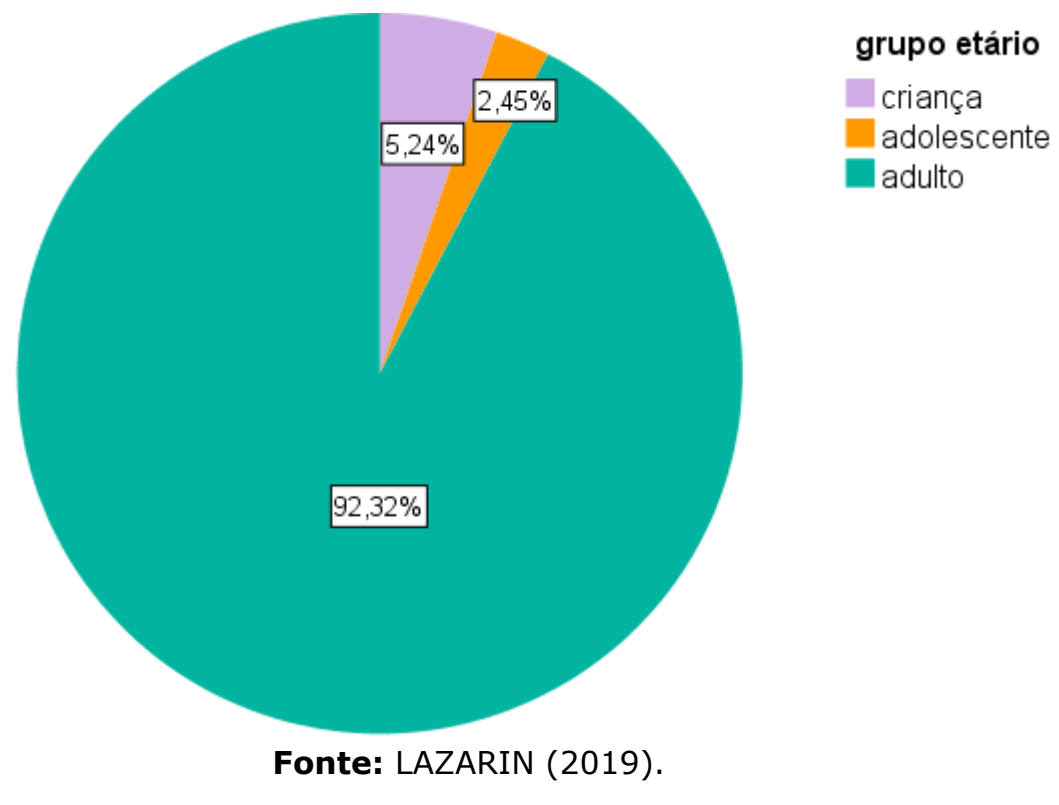

12 Sobre o entendimento dos campos como regimes de exceção, Agier (2006, p. 199) afirma: "[...] o funcionamento, as perversões e as corrupções dos sítios humanitários podem ser atribuídos a um regime de exceção no qual o arbitrário e seus atores agem livremente em sua própria ordem das coisas. Com a constituição dos terrenos do humanitário como espaços de exceção, como não-lugares, a história política recente fez nascer uma categoria mundial de sem-lugar e sem-direitos mais ampla que a soma dos refugiados propriamente ditos."

13 Foi alterada para "desconhecido" a idade de 6 indivíduos registrados como de 0 anos na tabela original. Esses não possuíam datas de nascimento, solicitação e decisão registrados. Todos estes constam enquanto de sexo masculino, 2 como casados, 2 solteiros e dois sem estado civil registrado. Todos constam como sendo do Senegal e tendo solicitado o refúgio na cidade de Rio Branco. Tais processos também possuíam o status de pendentes. O fato de alguns destes registrados como tendo 0 anos também constarem enquanto casados pôs dúvida a concreticidade das informações destes solicitantes. Devido ao déficit de informação sobre idade, com o registro de datas importantes, tais processos foram excluídos da análise do grupo infantil, passando para o grupo "desconhecido". Também os processos que tinham a idade constando com algum valor negativo na tabela original foram substituídas para "desconhecidas" (um total de 39 casos). ${ }^{14}$ Considerando-se crianças aqueles que tinham de 0 a 11 anos no momento da solicitação, adolescentes aqueles entre 12 e 17 anos e adultos os maiores de 18 anos. 
A idade na solicitação sugere que a busca pelo Brasil como país de refúgio é viabilizada por aqueles que estão na idade economicamente ativa como ilustra o gráfico, na figura $2^{15}$. Nele verifica-se uma ampla concentração do número de solicitações entre as idades de 18 e 40 anos, sendo a mediana da idade dos solicitantes é de 28 anos.

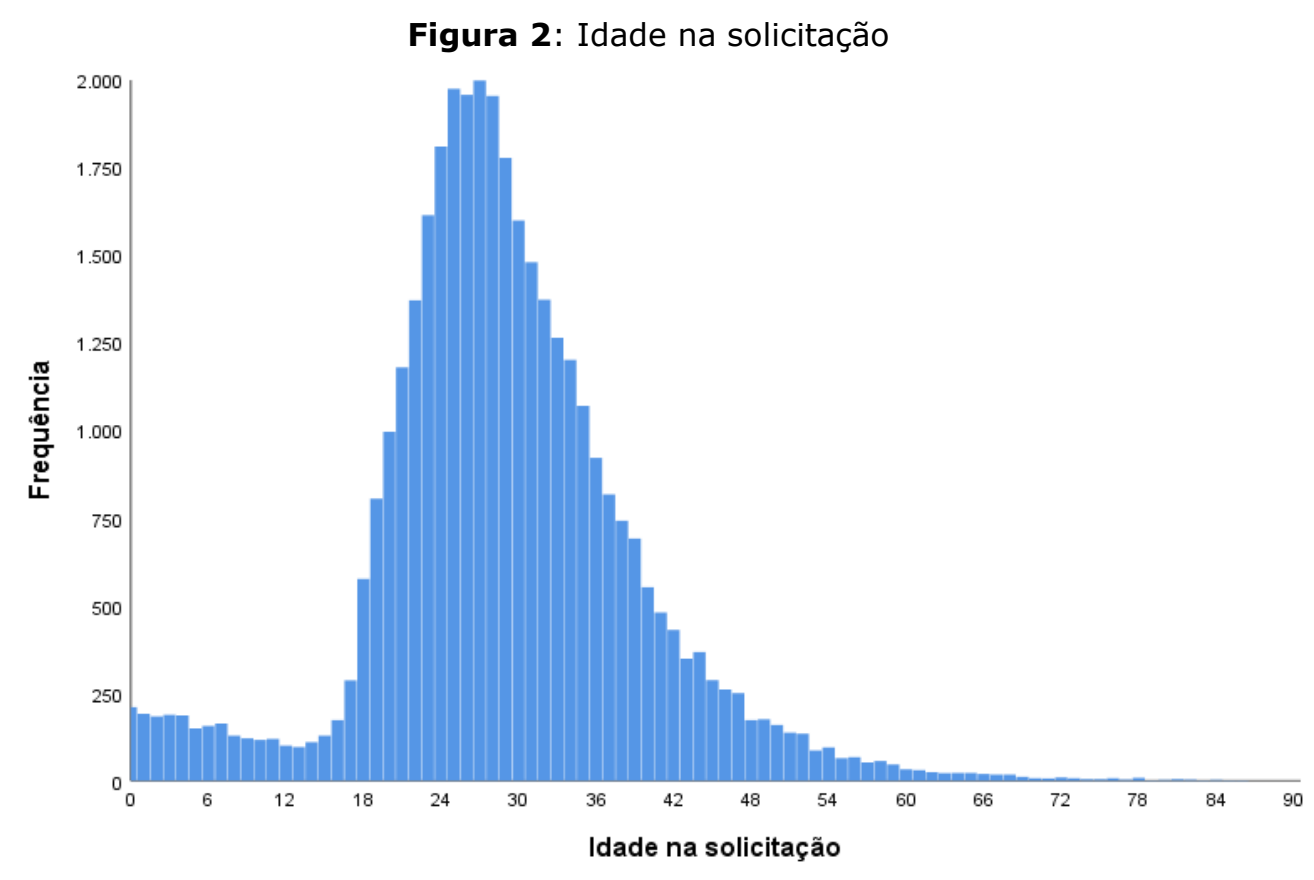

Fonte: LAZARIN (2019).

Outro dado importante a ser analisado com a informação acima é o de gênero: $82,5 \%$ dos processos são de pessoas do sexo masculino ${ }^{16}$. Assim, como já referido por outras pesquisas (CALEGARI, 2014), a população que vem buscar refúgio no Brasil é adulta e do gênero masculino. Pensando com Jardim (2007), isso tem muita relação com a posição do Brasil na ordem global e os fluxos que atrai.

Já quanto ao gênero das crianças, existe uma equidade bem maior entre os solicitantes: $55,2 \%$ masculino, $44,8 \%$ feminino. O gráfico abaixo (Figura 3) mostra a taxa de homens e mulheres por grupo etário, sinalizando a predominância de solicitações do sexo masculino em todas as gerações, mas havendo maior equidade entre os mais jovens.

\footnotetext{
${ }^{15}$ Contabilizados 36.481 casos em que era descrito a idade de solicitação, os outros 2.301 casos contando como "desconhecidos" foram categorizados como omissos.

16 Dos dados válidos, ou seja, desconsiderando os 596 casos que constavam como "desconhecidos" na variável "sexo".
} 
Figura 3: Sexo por grupo etário

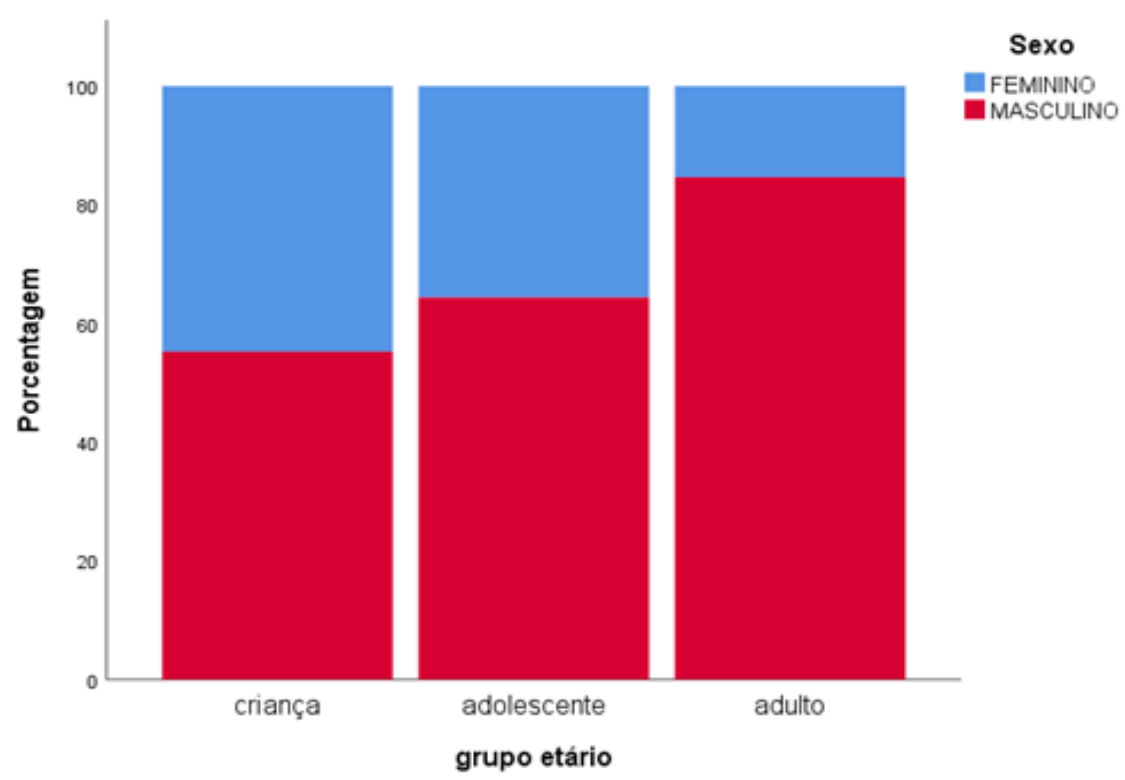

Fonte: LAZARIN (2019).

Outro dado que se destaca na análise das solicitações é que 54,32\% eram de pessoas vindas do continente africano. Em relação à origem geográfica, os dados estão divididos em oito categorias, que seguem com a respectiva frequência de casos: África (21.066), América Central (2.142), América do Norte (35), América do Sul (3.132), Ásia (5.819), Europa (990), Oriente Médio (5.586), além de Apátridas (12) ${ }^{17}$.

Porém, se existe no cenário geral a predominância de pessoas com origem em países africanos, quando cotejado a origem por grupo etário vemos que isso se dá sob influência dos adultos; não sendo tal dominância averiguada na mesma intensidade entre as crianças e adolescentes (Figura 4). Como mostra o gráfico a seguir, apesar da África constituir o lugar de origem mais comum entre as crianças e adolescentes, existe uma quase igualdade percentual com o Oriente Médio no grupo infantil. Além disso, se tornam mais numerosos os casos originários da América do Sul e da Europa frente à Ásia; contrariamente ao panorama no universo adulto.

17 Mantendo as mesmas subdivisões de continente de origem da tabela original do Conare. 
Figura 4: Continente de origem dos solicitantes por grupo etário

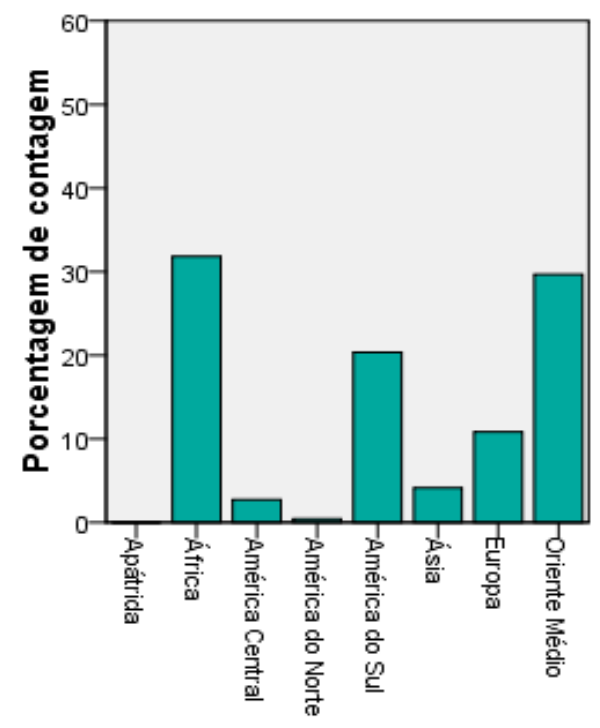

criança

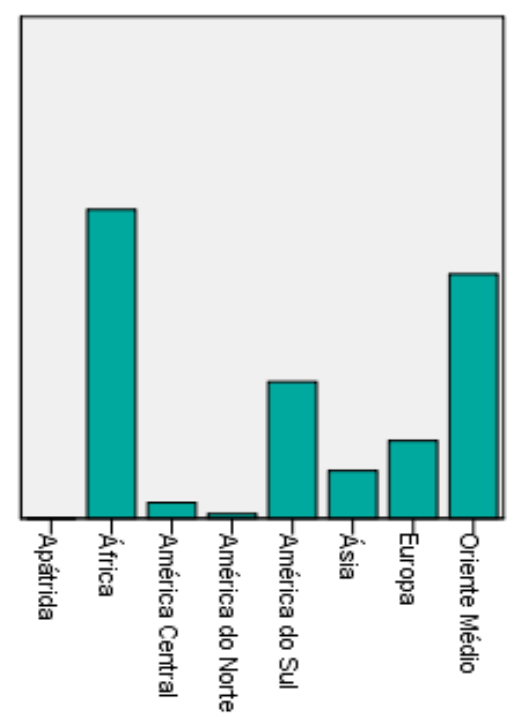

adolescente

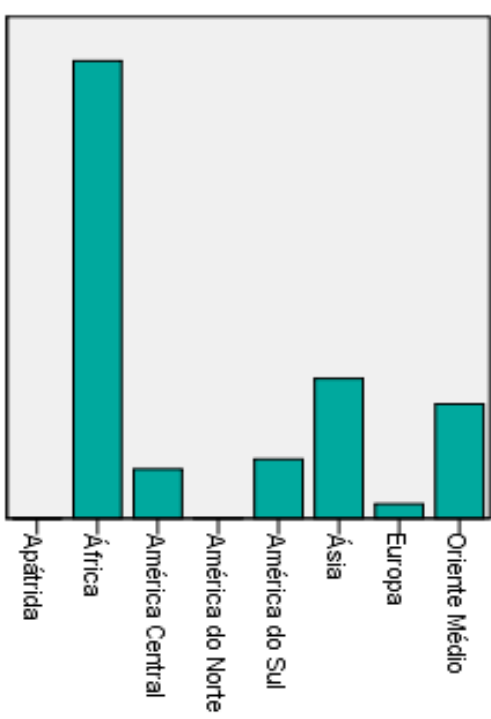

adulto grupo etário por continente de origem

Fonte: LAZARIN (2019).

A discrepância entre o pico da quantidade de solicitações do continente africano em relação às demais origens no grupo adulto não é verificada entre as crianças. Entre elas, o Oriente Médio tem proporção quase equivalente à África e a América do Sul. Outro ponto que se destaca é a inversão entre Ásia e Europa: enquanto nos processos de crianças, a Ásia aparece em baixa, sem porcentagem tão significativa, e a Europa aparece com certa elevação; entre os adultos o cenário é inverso, a Ásia tem maior participação do que a Europa (inclusive maior também do que a própria América do Sul). A distribuição das solicitações de crianças conforme o continente de origem, portanto, ficam como mostra o gráfico de setor (Figura 5). Nele, os rótulos representam o número de crianças registradas de acordo com cada origem, revelando a proximidade entre o número de solicitações do África e Oriente Médio, com, respectivamente, 608 e 567 casos. 
Figura 5: Continente de origem das solicitações de crianças

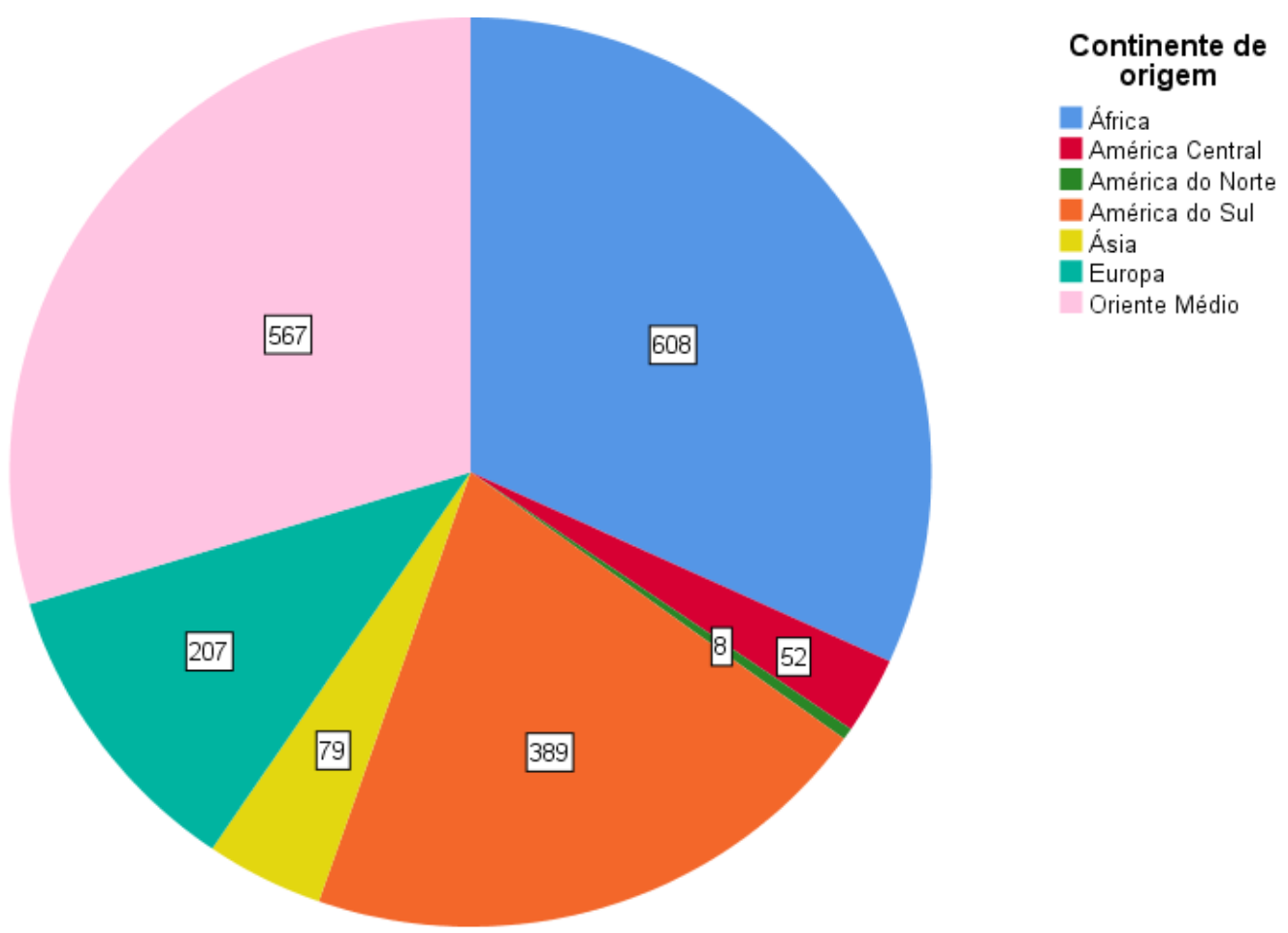

Fonte: LAZARIN (2019).

A não manutenção da proporção dos continentes de origem nas solicitações conforme o grupo etário - lança luz à existência de contextos emigratórios, nos quais crianças têm a possibilidade maior de se deslocar para o Brasil: não sendo o padrão migratório, portanto, o mesmo entre adultos e crianças. Talvez essa argumentação fique mais evidente com o gráfico a seguir, no qual se ilustra a composição percentual de crianças, adolescentes e adultos em conformidade com cada continente de origem. Percebemos que a participação das crianças, bem como dos adolescentes, se dá de forma distinta a depender do continente de origem de que partem os fluxos. Apesar do montante das solicitações de países do continente africano ser mais numerosa, a participação de criança é de cerca de 3,1\%; enquanto dos países do continente europeu é de aproximadamente $23,5 \%$ e da América do Norte 22, $8 \%$. Já a América do Sul e Oriente Médio ficam em posições intermediárias, com, respectivamente, 13,3\% e $10,4 \%$ de participação infantil. Ásia, América Central, por sua vez, ficam com as menores proporções entre os grupos etários, com, respectivamente, 1,4\% e 2,5\% de crianças no montante das solicitações dos países desses continentes ao Brasil (ver Figura 6). 
Figura 6: Composição de grupos etários conforme os continentes de origem das solicitações

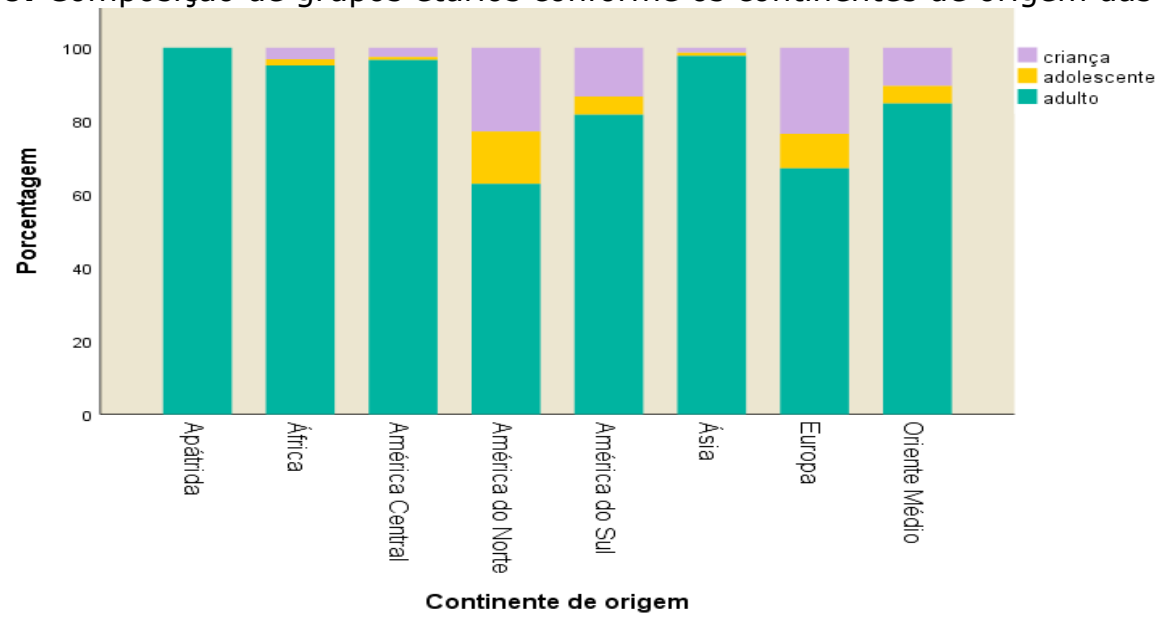

Fonte: LAZARIN (2019).

Pelo exposto, inferimos que, existem maiores números absolutos de crianças solicitantes de refúgio conforme espaço de origem, enfatizando que também estão imersas nos conflitos geopolíticos globais; quando se compara a proporção entre adultos e crianças em cruzamento ao continente de origem, percebe-se a existência de fluxos específicos, em que há maior possibilidade das crianças emigrarem para o Brasil. Existem contextos de crises nacionais que as atingem com maior intensidade, mas isso não significa que elas emigrem mais. Existem lugares de onde elas mais saem (como do continente africano), todavia, existem também fluxos em que elas têm maior possibilidade de participar (como dos fluxos América do Norte-Brasil e Europa-Brasil), não sendo esses dois aspectos diretamente relacionados.

É relevante pormenorizar os lugares de onde emergem solicitações de refúgio para crianças no Brasil, diminuindo a escala do continente para o país de origem. Redimensionando a escala, da África, destacam-se dois países, Angola e República Democrática do Congo, que somam $75 \%$ do total das 608 solicitações de crianças do continente. Da Ásia, o país com o maior número de solicitações é o Sri Lanka, com 35. Somando as do Afeganistão, Bangladesh e Irã com as do Sri Lanka têm-se 74 das 79 solicitações de refúgio por crianças da Ásia. Já da Europa, a Romênia sozinha tem quase $93 \%$ dos requerimentos infantis. Do Oriente Médio, a Síria é o país com maior número de solicitações, com 365. A Palestina e o Líbano aparecem em segundo e terceiro lugar, respectivamente, das solicitações de refúgio de crianças de lá, com 74 e 72 pedidos.

Passando para as Américas, tem-se que, da América central, Cuba é o país com a maior parcela de tais solicitações, com 28 requerimentos, enquanto a República Dominicana fica em segundo lugar, com 18 solicitações de crianças; juntos, os dois países somam cerca de $89 \%$ das solicitações. Da América Norte, o único país que não 
consta com crianças solicitantes de refúgio é o Canadá; Estados Unidos possuem 5 e México 3. Dos países da América do Sul, por sua vez, a Colômbia aparece com grande destaque, com 246 casos de solicitações em um total de 389. Juntamente com a Bolívia e a Venezuela, o percentual dos três países é de aproximadamente $94 \%$ dos pedidos de auxílio do grupo infantil do continente sul americano.

Nesse cenário, tem-se que até abril de 2016, 5 fluxos migratórios eram responsáveis por mais de $65 \%$ do total das solicitações de refúgio por crianças registradas pelo Conare, identificados no mapa abaixo (Figura 7). Nele, a largura das setas estão proporcionais umas às outras, em relação ao número de solicitações de crianças da nacionalidade. Ou seja, dos 5 maiores países de origem dos quais as crianças pleiteavam reconhecimento ao Brasil, a Síria representava, até o momento, a maior demanda, com 365 casos; seguido pela Colômbia, com 256; pela República Democrática do Congo, com 239 pedidos; Angola, com 217; e, por fim, Romênia, com 192 solicitações de crianças.

Figura 7: Mapa dos principais fluxos de crianças solicitantes de refúgio ao Brasil, conforme o país de origem

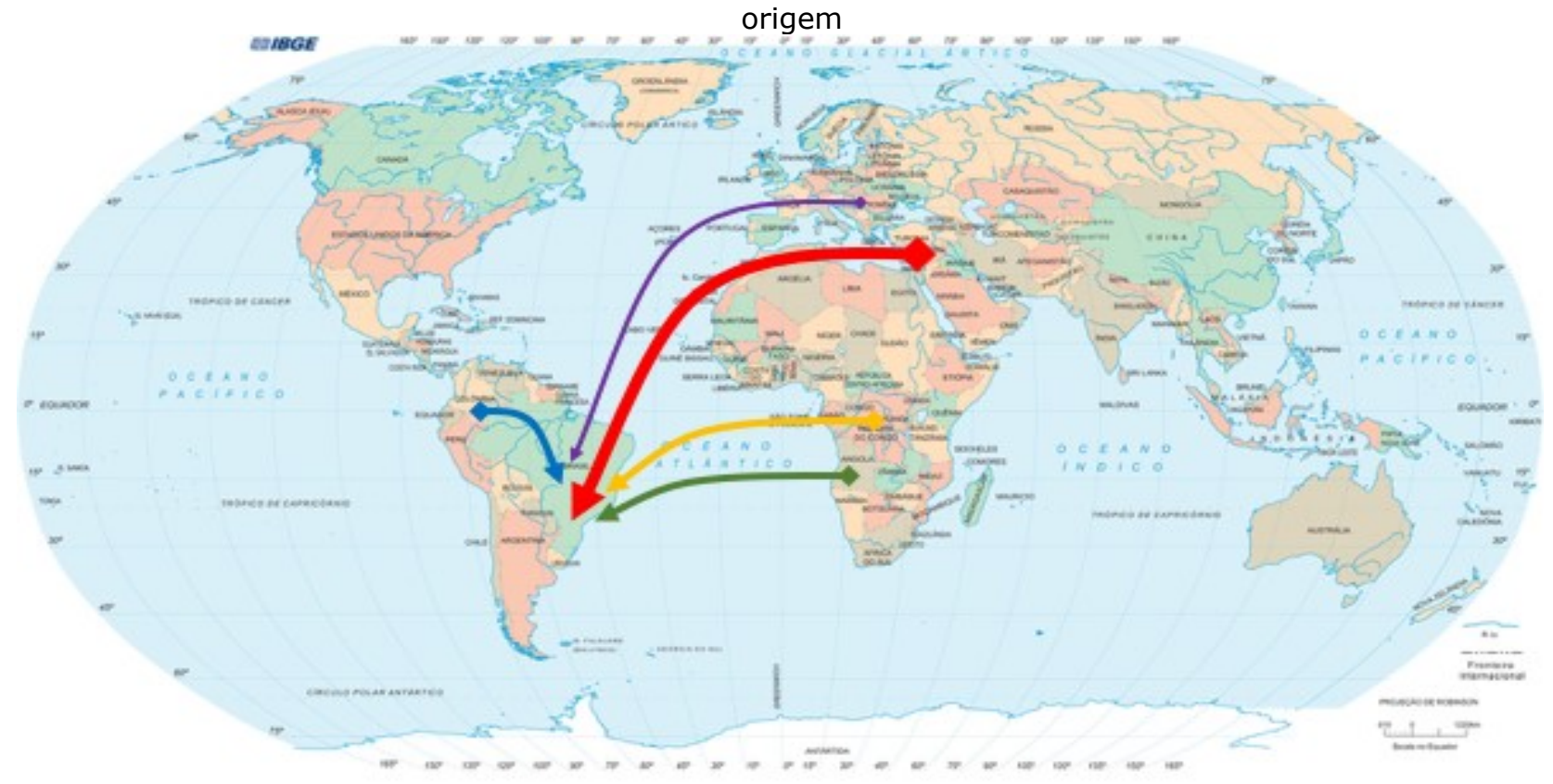

Legenda:
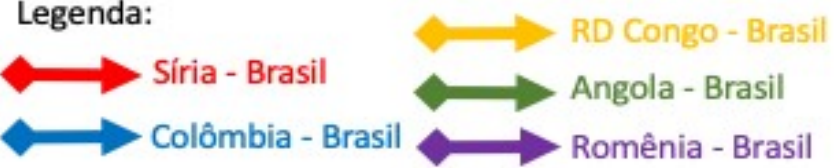

Fonte: IBGE (2019), Mapa-Múndi, Planisfério Político, adaptado por Lazarin (2019).

Além das origens diversas, existe no Brasil, dada sua extensão territorial, uma ampla possibilidade de entradas e fixação. Assim, foi criado um gráfico para representar a frequência por Unidade da Federação e a localização nestas: capital ou interior. Dado 
o número extenso de cidades onde ocorreram as solicitações, entendeu-se que melhor visualização dos dados aqui se daria a partir do entendimento de se tal localidade é capital ou não ${ }^{18}$. O gráfico (Figura 8) ilustra que a maioria das solicitações foi feita nas capitais, destacando-se as cidades de São Paulo, Brasília e Rio de Janeiro.

Figura 8: Local das solicitações das crianças

grupo etário

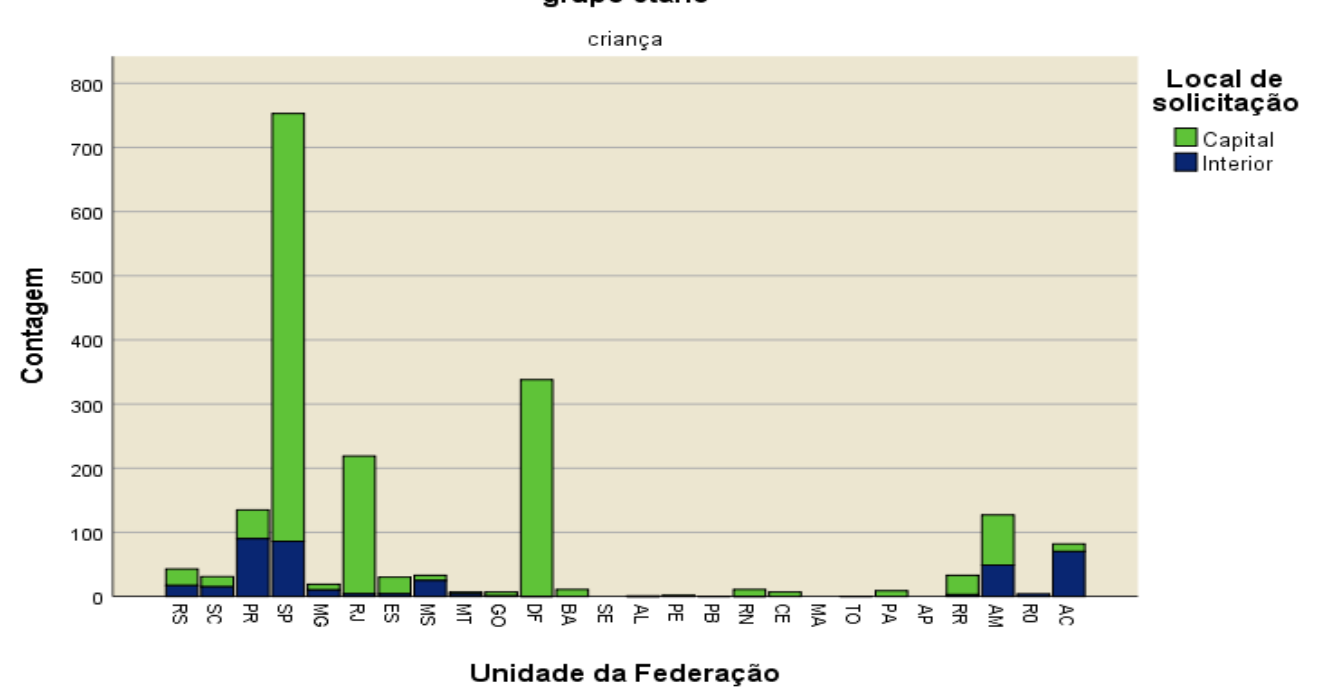

Fonte: LAZARIN (2019).

Considerando a relevância do continente de origem na especificidade migratória do grupo infantil, outro dado relevante a se pensar foi o local de solicitação das crianças, conforme os grupos de origem. São Paulo, por exemplo, aparece com relevância em todos os grupos, com exceção das crianças da América do Norte; sendo que no caso das crianças da África e do Oriente Médio o percentual das solicitações neste estado chega a ser de mais de $50 \%$. Nestes casos, não só a proporção interna ao grupo de origem se mostra grande, como também aponta a influência no total das crianças solicitantes, pois, conforme visto anteriormente, crianças africanas e do Oriente Médio constituem os grupos com maior número de solicitações de refúgio no Brasil.

Passando às Américas, há que se frisar a existência de apenas oito solicitações de crianças norte americanas: três no Rio de Janeiro, duas em Santa Catarina, duas no Rio Grande do Sul e uma em Roraima. As solicitações da América Central têm uma distribuição mais diversificada, tendo seis unidades federativas com proporção bastante parecida. Contudo, se não existe grande destaque para um Estado, é possível perceber

\footnotetext{
18 Para isso, a partir da variável "Cidade de Solicitação" foi criada uma outra variável no Excel, em que calculamos, a partir de uma lista suspensa e pelo comando PROCV, se o nome correspondente e na planilha do Conare estava entre os nomes da lista de capitais. Se sim, na nova variável, volta-se o termo "Capital", se não, "Interior". Posteriormente os termos foram substituídos por 1 e 2 e adicionados no SPSS para análise.
} 
que há uma concentração das solicitações no Norte do país, pois três, dos seis estados, são desta região (Acre, Roraima e Amazonas). Das sul americanas, o Amazonas detém a faixa de maior significância numérica; e, assim, como as solicitações da América Central, evidencia-se a predominância da região Norte. Tanto da Ásia quanto da Europa, o Distrito Federal compreende a unidade federativa de maior percentual de solicitações de refúgio para crianças, sendo que no caso Europeu, essa fatia chega a ser de $87 \%$.

Considerando essa diversidade de rotas, algumas concentrações de solicitação de crianças se estabelecem conforme o local de origem e local de registro do requerimento, como mostra o mapa a seguir (Figura 9). Nele estão representados os casos em que a nacionalidade de criança e a unidade da federação se cruzam em 30 ou mais vezes; e o tamanho da circunferência está escalado em proporção à intensidade da frequência. Importante informar que as marcações do mapa, tal como dito na legenda, referem-se ao cruzamento do país de origem com a Unidade da Federação na qual foi realizada a solicitação de refúgio, e não às cidades.

Figura 9: Mapa de concentração das solicitações de crianças conforme a nacionalidade e Unidade da Federação

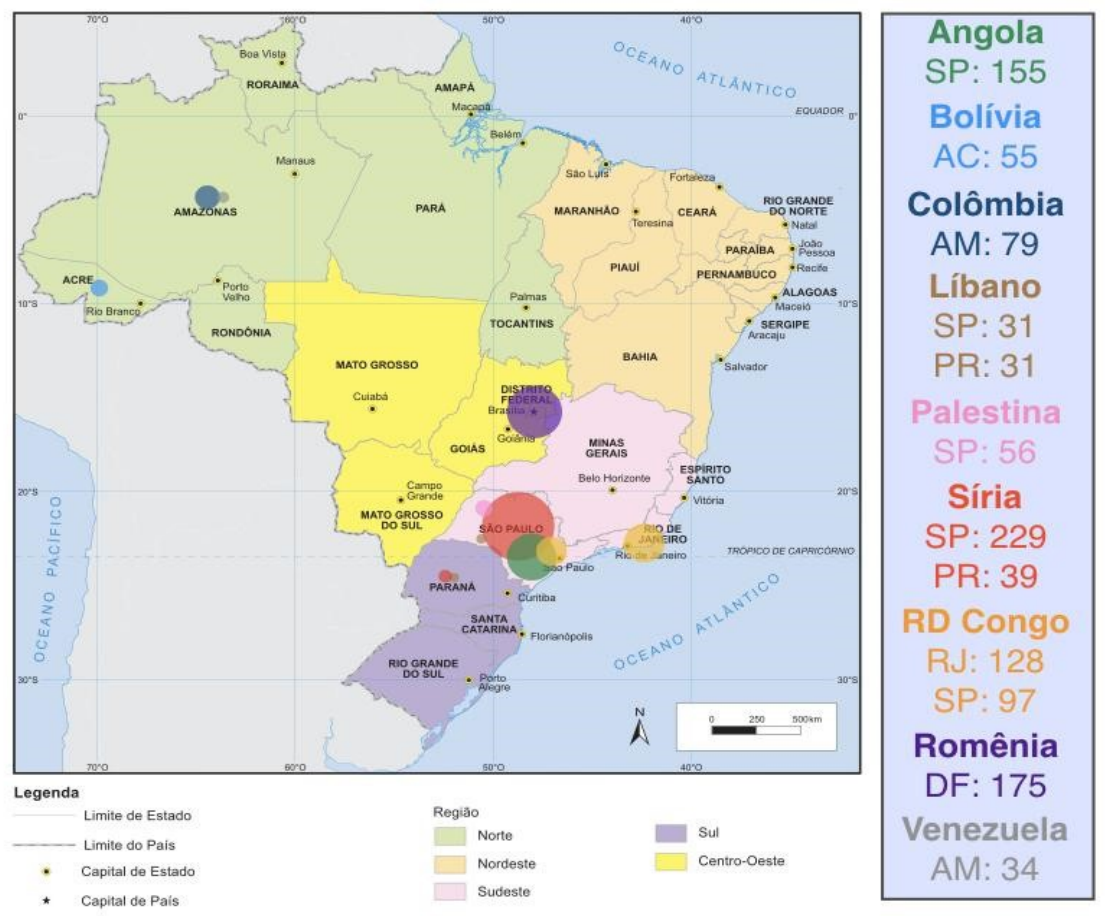

Fonte: IBGE (2019), Mapa Político do Brasil, adaptado pela autora.

O maior agrupamento infantil de crianças solicitantes de refúgio por Unidade da Federação refere-se, portanto, às crianças sírias em São Paulo, com 229 casos. Outro agrupamento significativo é das romenas que registram a solicitação no Distrito Federal. O fluxo das crianças congolesas aparece bem dividido entre São Paulo e Rio de Janeiro. 
No norte do país, o maior destaque trata-se das colombianas no Amazonas. No Brasil, portanto, São Paulo ainda aparece como o estado de grande destaque, onde as solicitações de crianças são realizadas, sobretudo, como ilustrado anteriormente (vide Figura 8), na capital.

Por fim, é importante detalhar melhor a variável gênero dentro do grupo infantil. Se, no início deste tópico, apontou-se que existe uma proporção muito parecida entre meninas e meninos solicitantes, essa razão não se mantém constante ao cruzar a variável sexo com o país de origem, conforme se observa no gráfico a seguir (considerando os países com percentual maior que $1 \%$ das solicitações de crianças ver Figura 10).

Figura 10 - Sexo por Nacionalidade entre as crianças solicitantes de refúgio

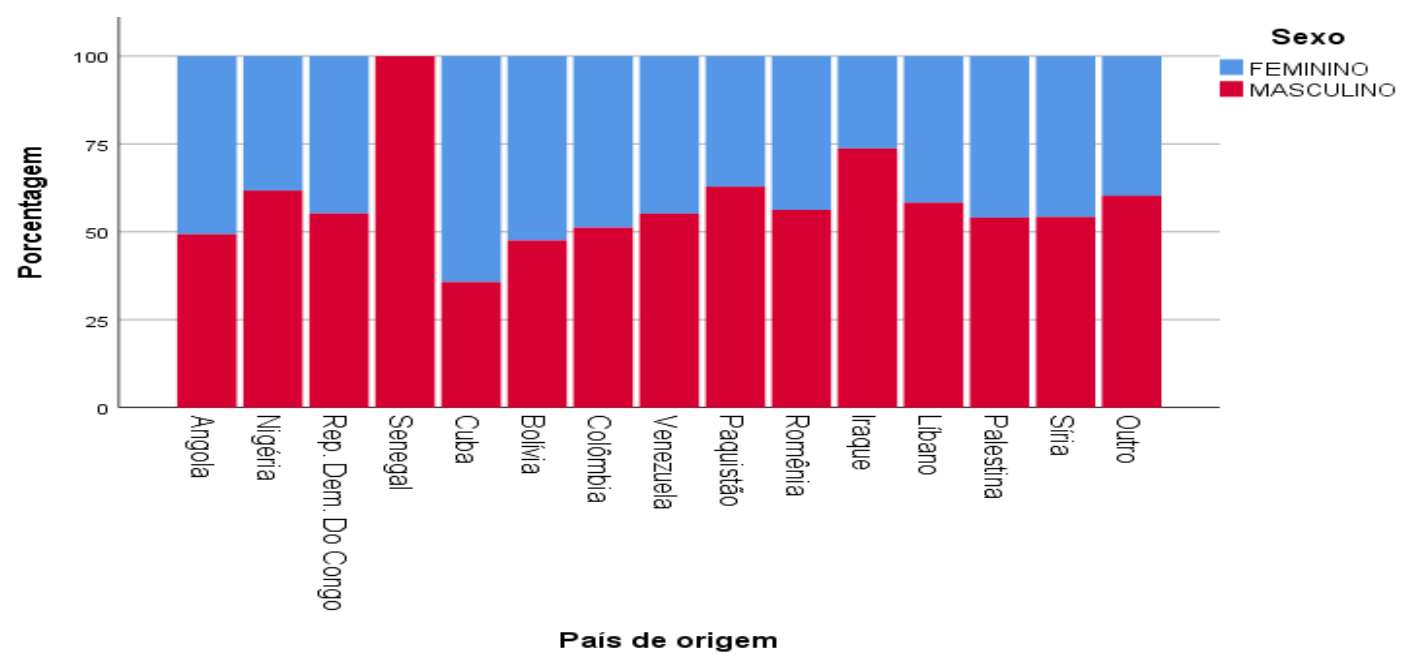

Fonte: LAZARIN (2019).

A disparidade é mais notória nas solicitações do Senegal, nesse caso, todas as solicitações são de crianças do sexo masculino. Esse padrão aparece em consonância ao perfil geral (sem especificação por faixa etária) dos Senegaleses no Rio Grande do Sul, levantado por Uebel (2016). Em sua pesquisa, o autor atribui à religião mulçumana a preponderância de homens senegaleses no Brasil ${ }^{19}$.

\footnotetext{
19 Referenciando os dados da CIA World Factbook para o Senegal, ele afirma: "[...] a participação das mulheres na população economicamente ativa do Senegal ainda é restrita e restringida àquelas que não professam a religião islâmica - cerca de $94 \%$ da população senegalesa é muçulmana - o que justifica uma participação diminuta de mulheres imigrantes senegalesas tanto no Brasil como no Rio Grande do Sul, correspondendo apenas a 1,6\% do estoque imigratório neste estado" (UEBEL, 2016, p.70). No caso das crianças, por não adentrarem na população economicamente ativa, se mostra relevante a elaboração de estudos que pesquisem tal questão.
} 
Outro caso em que se destaca o sexo masculino é o Iraque, sendo composta por cerca de $75 \%$ das solicitações de meninos. O único país que possui porcentual significativamente maior de solicitações de meninas é Cuba.

Os dados aqui abordados direcionaram o olhar para o entendimento das solicitações de refúgio que foram feitas para o Brasil até abril de 2016. Destacam, portanto, não sobre o direito de imigrar no país, mas - principalmente - sobre a necessidade e a oportunidade de emigrar. A literatura ${ }^{20}$ mostra que em contexto de dificuldade, sobretudo a financeira, a prioridade é dada à emigração daqueles que seriam mais facilmente integráveis - visando, no caso, a inserção no mercado de trabalho. As crianças, em geral ${ }^{21}$, têm que esperar o momento propício, em termos de estratégias familiares e de recursos, para conseguir se deslocar. Os dados ilustram as discrepâncias no percentual de solicitações por grupo etário e continente de origem, evidenciando que não existe correlação total e direta entre a taxa de migração adulta com a infantil. Para entendê-los é preciso considerar que contextos sociogeográficos estão relacionados a oportunidades distintas de emigração infantil. Assim, o direito de emigração das crianças apresenta-se como impossível de ser refletida somente às sombras da emigração adulta: não necessariamente acompanham os fluxos da mesma maneira - numericamente e socialmente falando. Esse argumento corrobora com Martuscelli (2015), que argumenta ser necessário refletir as crianças como agentes de importância dentro dos fluxos migratórios.

Portanto, os dados evidenciam que, por exemplo, dentro das solicitações de refúgio mais numerosas, o Oriente Médio, América do Sul e Europa existe um percentual relativo maior de crianças, sinalizando para grupos sociogeográficos com maior índice de possibilidade de deslocamento forçado das crianças para o Brasil. Obviamente, no caso da América do Sul é importante se levar em consideração a proximidade territorial e, em decorrência, o menor montante de recursos necessários para o fluxo. Mas, os dados levam a refletir também sobre quais crianças têm ou não que solicitar o refúgio: o número escasso de casos da América do Norte é um indicador disso, por mais que

\footnotetext{
20 "Se, por um lado, a criança tem mais habilidades para se deixar impregnar por impressões novas, está mais aberta à aprendizagem e é mais capaz de assimilar uma nova língua e costumes, por outro, existem carências especiais, pois não participaram da decisão de sua família ao mudar e geralmente não compreendem as motivações que os pais tiveram. Além disso, a explicação sobre essa situação à criança nem sempre acontece" (UENO, 2010, p. 6).

${ }^{21} \mathrm{O}$ caso das crianças desacompanhadas requer um olhar outro sobre a forma como se dá a migração infantil. No Brasil, até 2016 ela não se apresentava como numericamente significativa, mas tem se ampliado no cenário do fluxo venezuelano. Ver: https://www1.folha.uol.com.br/mundo/2019/12/cada-vezmais-criancas-venezuelanas-chegam-desacompanhadas-ao-brasil.shtml
} 
seja o segundo fluxo de um continente para o Brasil com maior porcentagem de participação de crianças.

É importante também considerar que a variável gênero, nacionalidade e grupo etário se conjugam de maneira muito distinta. Os solicitantes de refúgio adultos são, em sua maioria, do sexo masculino; já entre as crianças existe uma proporção mais equânime entre a quantidade de meninos e meninas. Todavia, quando desmembrado este dado por nacionalidade, percebe-se que existem variações do gênero das crianças solicitantes conforme o país de origem. Esse olhar sobre o gênero na migração infantil é necessária, pois as meninas refugiadas estão mais expostas, no cenário internacional, a uma série de violências, como, por exemplo, o não acesso à escola (Grajzer, 2018).

Conforme a perspectiva teórica sobre os significados de se demandar refúgio, sabe-se que a nacionalidade não é mais totalmente explicativa para entender grupos que buscam o refúgio. Obviamente existem limites dos dados sumarizados, que não conseguem transmitir toda a complexidade por traz dos casos. Mas, com Bourdieu (2008), podemos pensar que o espaço geográfico é, de certa forma, transmutado em social, e vice-versa; é o que o autor nomeia de efeitos de lugar. O lugar de origem denota a localização de um corpo no espaço não só âmbito espacial/geográfico/físico, como também se relaciona com outras posições: os agentes sociais são constituídos nas e pelas relações com o espaço social ${ }^{22}$. De onde partem as crianças, o território e o Estado soberano nele circunscrito, apontam zonas de existência em que uma atuação de não proteção ou perseguição que é revertida na busca de em um outro Estado$\mathrm{Nação}^{23}$. No caso dos dados aqui em análise, refletem-se crianças ante a política de expulsão em que uma das estratégias é migrar para o Brasil. No panorama mundial existiriam outros espaços significativos de onde saem tais crianças, esse é só um recorte de todo esse fluxo forçado das quais as crianças fazem parte.

\section{NOTAS FINAIS}

Com este estudo, ressalta-se a especificidade da forma como infância e refúgio vêm se relacionando e sendo constituída no Brasil. Percebe-se, por exemplo, que os

\footnotetext{
22 Esse texto de Bourdieu (2008) vai no mesmo sentido com o de Lopes (2003), quando aponta que os estudos sobre identidade cultural dão destaque a vinculação com o território, ademais, a construção social do ser criança é atravessado pelas variáveis espaço e tempo.

23 É importante destacar que estamos falando da travessia entre fronteiras estatais, porque nem sempre a situação de conflito possibilita um deslocamento mais longínquo, pois, segundo o Unicef (2016), muitas crianças estão deslocadas internamente.
} 
fluxos de refugiados direcionados ao Brasil ainda pouco contava com a participação de crianças. Em termos proporcionais, também se viu que dos movimentos que chegaram ao Brasil até abril de 2016, alguns possuíam proporção maior de crianças, ressaltando em quais existem recursos mínimos para bancar também os deslocamentos dos mais novos. Nesse sentido, fluxos como América do Norte-Brasil e Europa-Brasil apareceram com destaque na taxa de crianças dentre os solicitantes de tais continentes de origem, embora o maior número de crianças, em termos absolutos, que buscou refúgio no país seja da África e do Oriente Médio. Os cinco países de origem mais comuns das crianças eram Síria, Colômbia, República Democrática do Congo, Angola e Romênia.

Quanto à localização, mapeou-se que as crianças, que chegaram solicitando refúgio no país, o fizeram, sobretudo na região Sul, Sudeste e no Distrito Federal, com grande concentração em São Paulo (especificamente na maior cidade do país). Foi possível também observar, a partir da intersecção das variáveis 'país de origem' e 'local de solicitação', a existência de itinerários migratórios expoentes desses deslocamentos infantis, como é o caso das solicitações de crianças romenas no Distrito Federal e de sírias e angolanas no estado de São Paulo. Outras singularidades que a nacionalidade indicou trazer é referente ao sexo das crianças, pois se no panorama geral havia uma quase equivalência numérica entre meninas e meninos, quando fragmentado por local de origem, viu-se distintas proporções aparecerem.

Os dados, portanto, trouxeram questões importantes a se refletir sobre a forma como vem se configurando a infância refugiada no Brasil. Primeiro, ela não acompanhava proporcionalmente os fluxos internacionais, disso há que se pensar que a geopolítica de divisão dos Estados influencia os fluxos que podem imigrar ao Brasil. Ou seja, se em nível global crianças e adolescentes compõem a maioria dos refugiados, em nível nacional, elas não representavam tamanha proporção entre os solicitantes. Logo, as travessias de crianças refugiadas não adentram com intensidade nos percursos que trazem ao Brasil; levando a inferir que o deslocamento para o Brasil ainda não é uma das maiores oportunidades/estratégias quando envolvem fluxos infantis ou de familiares com crianças. Como segunda questão importante trazida pelo trabalho, para se pensar a formação dessa infância, sublinhamos não ser adequado simplesmente derivar a imigração infantil da adulta, afinal não tem as mesmas características de continente, nacionalidade e nem de gênero. Ou seja, as solicitações de crianças e de adultos não são proporcionais em escalas diferentes; são diferentes mesmo considerando a distinta grandeza numérica de cada uma. Isso não significa que os deslocamentos de crianças sejam independentes dos adultos: elas estão, na maior parte 
das vezes, imersas nas estratégias familiares, nas quais a decisão passa mais fortemente pela opinião dos adultos. Todavia, a análise da forma como os fluxos efetivamente se dão mostra que é preciso olhar não só a migração refugiada infantil e adulta em conjunto, como também separadamente; afinal, a interdependência não significa uma derivação mantendo semelhanças e proporções.

Estes levantamentos expostos dizem respeito, principalmente, ao momento de emigração com destino ao Brasil, isto é, quais saem do seu país e em suas travessias se direcionam ao país. Como visto, o refúgio reflete uma governamentalidade pela expulsão, assim, pensar as crianças que solicitam o refúgio nacionalmente indica, de certa forma, quais sofrem essa expulsão e viabilizam no Brasil um país de acolhida. Os números das solicitações são importantes, enfatizando ainda mais a geopolítica global que incidi diretamente sobre a vida das crianças. Quando se constata, por exemplo, que poucas solicitantes eram do continente norte americano, a pergunta que emerge é se essas têm um baixo nível de emigração emergencial ou se o Brasil é um país pouco procurado por essas crianças; cruzar com os dados globais se mostra, assim, imprescindível. Pelos dados do mapa global dos refugiados, com a divisão etária, do Unicef (2016), se constata que estas crianças de fato estão sob regimes biopolíticos que não põem tanto em risco suas vidas. Já no caso das crianças da África e do Oriente Médio existia uma incidência maior de crianças cuja existência no território de origem entra em conflito com as formas de governamentalidade da vida - estas são as que mais se refugiam, tanto ao nível nacional quanto global.

Se o Brasil, até então, recebeu um número menor de solicitações de crianças por refúgio, com a intensificação global dos conflitos nacionais, essa parece ser uma agenda importante a se ter em pauta, tendo que se preparar para recebê-las em maior quantidade; o fluxo venezuelano, por exemplo, já vem mostrando essa demanda infantil. Afinal, esse corpo criança é um dos corpos que estão mais vulneráveis ante as situações de tais conflitos. Não somente por suas singularidades biopsicológicas, mas por não terem supridas a mínima dependência de infraestrutura para sobrevivência. Não ter essa sólida "rede social de ajuda" (BUTLER, 2018) é indicativo de que essa vida não angariou os esforços necessários para se fazer vivível, uma vida cuja importância não é totalmente reconhecida. Como Butler (2018) sugere, não se nasce e depois se torna precário: a precariedade é marca do próprio nascimento, significando que uma criança sobreviver ou não é, sob esse viés, mais do âmbito social do que biológico. A precariedade que marca a vida das crianças migrantes é, assim, não símbolo de sua fraqueza, todavia um símbolo de sua vulnerabilidade perante as formas de 
governamentalidade das pessoas - governamentalidades territorializadas no âmbito de um país, mas que se repercutem para além das fronteiras estatais. É sobre isso que este artigo tratou, a reverberação dos conflitos - que atinge a vida de muitas crianças pela expulsão - no Brasil, a partir dos dados quantitativos de solicitação por refúgio no Conare: uma faceta da formação da infância refugiada a nível nacional.

\section{REFERÊNCIAS}

AGAMBEN, Giorgio. Homo Sacer: o poder soberano e a vida nua I. Belo Horizonte: Editora UFMG, 2002.

AGAMBEN, Giorgio. Estado de exceção: Homo Sacer, II, I. São Paulo: Boitempo Editorial, 2007.

AGÊNCIA DA ONU POR REFUGIADOS [ACNUR]. Global Trends: Forced Displacement in 2018. Disponível em < https://www.unhcr.org/5d08d7ee7.pdf> acessado em: 04. dez. 2019.

AGIER, Michel. Refugiados diante da nova ordem mundial. Tempo Social, v. 18, n. 2, p. 197-215, 2006.

ANDERSON, Benedict. Comunidades imaginadas: reflexões sobre a origem e a difusão do nacionalismo. São Paulo: Editora Companhia das Letras, 2008.

APPADURAI, Arjun. Soberania sem territorialidade. Revista Novos Estudos CEBRAP, v. 49, p. 33-46, 1997.

BENHABIB, Seyla. O declínio da soberania ou a emergência de normas

cosmopolitanas? Repensando a cidadania em tempos voláteis. Civitas. Porto Alegre, v. 12, n. 1, p. 20-46 jan. - abr., 2012.

BOURDIEU, Pierre. Efeitos de lugar. In: BOURDIEU, Pierre. A Miséria do mundo. Petrópolis: Vozes, 2008. P. 159-166.

BUTLER, Judith. Quadros de guerra: quando a vida é passível de luto. 4. ed. Rio de Janeiro: Civilização Brasileira, 2018.

CALEGARI, Marília. Refúgio e dinâmica familiar no Brasil. VI Congreso ALAP:

Dinámica de población y desarrollo sostenible con equidad, 2014.

DE CARVAlHO, José Murilo. Cidadania: tipos e percursos. Revista Estudos Históricos. v. 9, n.18, p.337-360, 1996.

ELIAS, Nobert. A sociedade dos indivíduos. Rio de Janeiro: Zahar, 1994.

FELIX, Jorge. Saskia Sassen: "Não é imigração, é expulsão". Ponto-e-Vírgula, São Paulo, n. 18, p.171-179, 2015. 
FOLHA DE SÃO PAULO. Cada vez mais crianças venezuelanas chegam

desacompanhadas ao Brasil. Disponível em <

https://www1.folha.uol.com.br/mundo/2019/12/cada-vez-mais-criancas-

venezuelanas-chegam-desacompanhadas-ao-brasil.shtml> acessado em: 23 de

Março. 2020.

FOUCAULT, Michel. Em defesa da sociedade: curso no Còllege de France (19751976). São Paulo: Martins Fontes, 1999.

FOUCAULT, Michel. Segurança, território, população: curso dado no Còllege de France (1977-1978). São Paulo: Martins Fontes, 2008.

FOUCAULT, Michel. O sujeito e o poder. In: Ditos e escritos, v.8. Rio de Janeiro: Forense Universitária, 2012.

FRAZÃO, Ana Carolina. Uma breve análise sobre o direito à nacionalidade. Jus Navigandi, v.4, n. 46, 2000.

GRAJZER, Deborah Esther. Crianças refugiadas: um olhar para infância e seus direitos. 2018. Dissertação (Mestrado em Educação) - Universidade Federal de Santa Catarina, Centro de Ciências da Educação, Programa de Pós-Graduação em Educação, Florianópolis, 2018.

JARDIM, Denise F. Imigrantes ou Refugiados? Tecnologias de controle e as fronteiras. Jundiaí: Paco Editorial, 2017.

LAZARIN, Monique Roecker. Quando A Infância Pede Refúgio: os processos de crianças no Comitê Nacional para os Refugiados. 2019. 130f. Mestrado (Dissertação) Programa de Pós-Graduação em Sociologia, Universidade Federal de São Carlos, São Carlos, 2019.

LOPES, Jader Janer Então somos "mudantes": Espaço, Lugar e Territórios de Identidade em crianças migrantes.2003. Tese (Doutorado em Educação). Universidade Federal Fluminense. Niterói. 2003.

MARTUSCELLI, Patrícia Nabuco. O paradoxo da globalização e a migração infantil: algumas reflexões. In: VASCONCELO, A. M. N; BOTEGA, Tuíla. Política migratória e o paradoxo da globalização. Porto Alegre: EdiPucRS, 2015.

MBEMBE, Achille. Necropolítica. São Paulo: n-1 edições, 2018.

PERALVA, Angelina; DA SILVA TELLES, Vera (Ed.). Ilegalismos na globalização: migrações, trabalho, mercados. Rio de Janeiro: Editora UFRJ, 2015.

QVORTRUP, Jens. Nove teses sobre a "infância como um fenômeno social. ProPosições, Campinas, v.22, n.1, p.199-211, jan./abr., 2011.

SASSEN, Saskia. Expulsões: brutalidade e complexidade na economia global. São Paulo: Paz e Terra, 2016.

TRINDADE, Maria Beatriz Rocha. Sociologia das migrações. Lisboa: Universidade Aberta, 1995. 
UEBEL, Roberto Rodolfo Georg. Panorama e Perfil da Imigração Senegalesa no Rio Grande do Sul no início do século XXI. Boletim Geográfico do Rio Grande do Sul. Porto Alegre, n. 28, p. 56-77, set. 2016.

UENO, Laura Satoe. Constituindo-se entre dois mundos: crianças na migração Brasil-Japão. X/ Congresso da BRASA (Brazilian Studies Association), Mesa "Educação e Migração: Práticas Educacionais" realizado em Brasília-DF. Jul, 2010.

UNICEF, United Nations Children's Fund. Uprooted: The growing crisis for refugee and migrant children. New York: set. 2016.

ZANFORLIN, Sophia Cavalcanti. A Construção Contemporânea Do Refugiado E Do Migrante: dos benefícios da condição de vítima à repreensão do protagonismo.

Perspectiva, v. 16, n.1, p.134-146. 2013.

\title{
NOTAS
}

\section{CRIANÇAS EM BUSCA DE REFÚGIO: REFLEXõES SOBRE AS SOLICITAÇÕES INFANTIS DE REFÚGIO AO BRASIL ATÉ 2016 \\ Children looking for refuge: reflections on child refugee requests to Brazil until 2016}

\author{
Monique Roecker Lazarin \\ Graduada em Ciências Sociais \\ Mestre em Sociologia \\ Universidade Federal de São Carlos \\ São Paulo, Brasil \\ moniquelazarin@gmail.com \\ https://orcid.org/0000-0001-7414-9738
}

Anete Abramowicz
Doutora em Educação
Faculdade de Educação
Professora da Universidade de São Paulo
São Paulo, Brasil
aneteabramo@gmail.com
Ohttps://orcid.org/0000-0002-4714-3602

Endereço de correspondência do principal autor

Rua Oscar Freire, n¹702, 05409-011, São Paulo, SP, Brasil.

\section{AGRADECIMENTOS}

Não se aplica.

\section{CONTRIBUIÇÃO DE AUTORIA}

Todos os autores contribuíram substancialmente.

\section{CONJUNTO DE DADOS DE PESQUISA}

Todo o conjunto de dados que dá suporte aos resultados deste estudo foi publicado no artigo e na seção "Materiais suplementares".

\section{FINANCIAMENTO}


O presente trabalho foi realizado com apoio da Coordenação de Aperfeiçoamento de Pessoal de Nível Superior - Brasil (CAPES) - Código de Financiamento 001.

\section{CONSENTIMENTO DE USO DE IMAGEM}

Não se aplica.

\section{APROVAÇÃo DE COMITÊ DE ÉTICA EM PESQUISA}

Não se aplica

\section{CONFLITO DE INTERESSES}

Não se aplica.

LICENÇA DE USO - uso exclusivo da revista

Os autores cedem à Zero-a-Seis os direitos exclusivos de primeira publicação, com o trabalho simultaneamente licenciado sob a Licença Creative Commons Attribution (CC BY) 4.0 International. Esta licença permite que terceiros remixem, adaptem e criem a partir do trabalho publicado, atribuindo o devido crédito de autoria e publicação inicial neste periódico. Os autores têm autorização para assumir contratos adicionais separadamente, para distribuição não exclusiva da versão do trabalho publicada neste periódico (ex.: publicar em repositório institucional, em site pessoal, publicar uma tradução, ou como capítulo de livro), com reconhecimento de autoria e publicação inicial neste periódico.

PUBLISHER - uso exclusivo da revista

Universidade Federal de Santa Catarina. Núcleo de Estudos e Pesquisas da Educação na Pequena Infância - NUPEIN/CED/UFSC. Publicação no Portal de Periódicos UFSC. As ideias expressadas neste artigo são de responsabilidade de seus autores, não representando, necessariamente, a opinião dos editores ou da universidade.

EDITORES - uso exclusivo da revista Márcia Buss-Simão e Kátia Agostinho.

HISTÓRICO - uso exclusivo da revista

Recebido em: 18-04-2020 - Aprovado em: 04-06-2020 